\title{
Asian Democracy through an Indian Prism
}

\section{ASHUTOSH VARSHNEY}

$\mathrm{T}_{1}$ EE ESSAYS IN THIS symposium are longing for completion. A heavy Indian shadow hangs over them. Asian democracy is the overall theme of the symposium, but India, Asia’s biggest "democratic behemoth," to use Edward Aspinall's phrase, is more or less missing. Why is a discussion of Indian democracy necessary for this symposium? What would it add to the arguments made here and the themes discussed?

Consider first the scale of India's democratic experience. Since 1952, when the first elections were held, India has had as many as sixteen national parliamentary elections and 351 state elections. Ruling parties have changed eight times in Delhi, and dozens of times at the state level. Until the early 1990s, there were virtually no elections at the local level, rural or urban. For four decades, only the national and state elections were regularly held. A constitutional amendment made local elections mandatory in 1992, adding three million local legislators elected every five years, a third of whom have to be women by law. In 1952, eighty-one million votes were cast. In the most recent national elections (2014), 66.6 percent of the electorate voted, accounting for nearly 555 million votes. Until 1989, following mainstream democratic theory, the richer and more educated citizens used to vote more than the poorer and the less educated. Over the last two and half decades, defying democratic theory, the poor and the less educated have voted as much as, if not more than, their more fortunate co-citizens (Yadav 2000). ${ }^{1}$

While voting is undoubtedly the strongest arm of India's democratic experience, many other elements of democracy are also present, if not as resolutely. With the exception of an eighteen-month-long emergency rule by Indira Gandhi, when opposition politicians were jailed, judges made pliant, and journalists forced to support the government, the judiciary has remained autonomous and has exercised its constitutional power to strike down laws and executive decisions. The press has also remained free. India's 1950 Constitution remains the bedrock of democratic functioning.

No discussion of Asian democracy will thus be complete without an account of India's immense democratic experience. How has India remained democratic for so long? Is India's democratic resilience really founded upon a deep political commitment to individual freedoms, which Daniel Chirot calls a requirement of democratic longevity? If Indonesian democracy is "illiberal," as Aspinall puts it, is Indian democracy by any chance profoundly liberal? Do we need to draw a distinction between electoral vibrancy and liberalism? How does India’s experience speak to the "Asian values" debate that Mark

\footnotetext{
Ashutosh Varshney (ashutosh_varshney@brown.edu) is Sol Goldman Professor of International Studies and the Social Sciences and Professor of Political Science at Brown University.

${ }^{1}$ The 2014 elections appear to be an exception. The middle and upper classes returned to the polling booths in large numbers (see Sridharan 2014).
} 
Thompson covers? How have Indian leaders dealt with the idea of a Rousseau-style mass participatory democracy, as opposed to a Schumpeterian electoral democracy, a key conceptual dichotomy in Elizabeth Perry's discussion of China?

In my discussion below, I will analyze Indian democracy both with respect to these questions and in light of democratic theory. My principal claim will be that India's electoral vibrancy is beyond doubt, but its democracy suffers from a gap. The polity's commitment to liberalism is not as strong. I will also examine at some length the foundations of electoral resilience. The causes of liberal deficits are not well understood. I shall summarize the key deficits, but a causal explanation of why they exist, despite electoral vibrancy, will have to await future work.

\section{A Theoretically Surprising Democratic Resilience}

It may be best to ground India's democracy theoretically before we invoke the comparative Asian perspectives. At the center of modern democratic theory stands the figure of Robert Dahl $(1971,1989)$. Some may wish to question this claim and give, instead, the pride of place to John Stuart Mill's work in the second half of the nineteenth century or Joseph Schumpeter's in the first half of the twentieth. But the fact remains that Mill, though seminal in many ways, has now been quite conclusively linked with defending British colonial empire on grounds that go against modern democratic principles — namely, that all human beings, despite their class or origins, have a capacity to deliberate about what is in their best interest. As Mehta (1999) has forcefully demonstrated, Mill divided the world into superior and inferior nations. Superior nations, such as England, deserved democracy, but inferior nations, such as India, could only have a "choice of despotisms" (Mehta 1999, 70-71). Mill also argued that the English should culturally lift Highland Scots and that Parisian France should enhance the "little mental orbit" of "the half savage" Basques. ${ }^{2}$ And Schumpeter (1947), while not a prisoner of Mill's assumptions about inferior and superior cultures, was beginning to make only the first forays into the existence of universal franchise, premised upon the idea of the equal dignity of all.

Dahl lent to the Schumpeterian idea - that elections were central to democracy-its most balanced conceptual anchorage. He placed the twin principles of contestation and participation at the heart of modern democracy (Dahl 1971). Contestation stands for the freedom with which one can challenge the all-powerful incumbents in an election, and participation signifies the extent of effective franchise-whether all citizens have the right to vote and whether they can freely vote. Dahl was in no doubt that such polities existed mostly in high-income Western societies, but acknowledged that "a leading contemporary exception ... is India, where [democracy] was established when the population was overwhelmingly agricultural, illiterate and ... highly traditional and rule-bound in behavior and beliefs" (Dahl 1989, 253).

\footnotetext{
2"Nobody can suppose that it is not beneficial to a Breton, or a Basque of the French Navarre, to be brought into the current of ideas and feelings of a highly civilized and cultivated people-to be a member of the French nationality ... than to sulk on his own rocks, the half-savage relic of past times, revolving in his own little mental orbit, without participation or interest in the general movement of the world. The same remark applies to the Welshman or the Scottish Highlander, as members of the British nation" (Mill [1861] 1990, 385-86).
} 
Should one think that Dahl thus unduly confined democracy to a mechanical voting exercise, an anathema to many on the left? For Dahl, democracy was both a dichotomous and a continuous variable. The first cut of the concept was dichotomous, for those polities that did not satisfy the minimal conditions - contestation and participation-were undemocratic. Singapore might have had participation in elections, but if the incumbent Lee Kuan Yew could not be effectively challenged for decades, then simply having regular elections would not make Singapore democratic (see Barr 2014).

However, once the threshold of contestation and participation was crossed, the binary would not hold. Countries could be more or less democratic, depending on how they conducted their lives between elections. How much did they subscribe to freedom of speech, religion, and association? The question of low-quality or high-quality democracy, raised by Aspinall, is relevant here. Once the thresholds of contestation and participation are satisfied, a democracy can indeed attain higher quality, or to use Dahl's own formulation, become deeper, if liberal freedoms between elections are available, religions are not repressed, all citizens are legally equal, and citizens are also free to speak, associate, and practice their faith. Dahl thus certainly states that we cannot have a democracy without free elections, but he also suggests that a democracy would be deeper if non-electoral dimensions of freedom, not simply free vote, were also available. It is in this way that a robust civil society is brought into the modern theory of democracy. It makes democracy deeper.

Notice that Dahl called Indian democracy an exception for, empirically speaking, democracy had great affinity with high income, and economically poor societies like India would not normally be democratic. This idea, associated with modernization theory for over five decades, has reached a remarkable statistical sophistication over the last two decades. Przeworski et al. (2000) constructed an international dataset covering 141 countries between 1950 and 1990, and found that income was the best predictor of democracy. It correctly predicted the type of regime in 77.5 percent of the cases; only in 22.5 percent did it not (Przeworski et al. 2000, 79). No other factor-religion, colonial legacy, ethnic diversity, international political environment-had the same predictive power. ${ }^{3}$

India was in the latter 22.5 percent set, along with some other Asian countries: Papua New Guinea, Solomon Islands, and Vanuatu. For Przeworski et al. (2000), India was the greatest surprise: “The odds against democracy in India were extremely high" (87). They also noted some exceptions on the other side: countries that should have been democratic on an income-based theory, but were not. Singapore "had a 0.02 probability of being a dictatorship in 1990" (87). If India was the biggest low-income surprise, Singapore was the greatest high-income exception in Asia.

This larger worldwide picture allows us to speak to an issue that Aspinall raises about Indonesia. He rightly notes that the democratization of South Korea and Taiwan, which began in the late 1980s and early 1990s, is consistent with the income-based theory. But, still being a lower middle-income country, ${ }^{4}$ Indonesia’s post-Suharto experience is not.

\footnotetext{
${ }^{3}$ Also see the critique of Przeworski et al. by Boix and Stokes (2003).

${ }^{4}$ According to the World Bank classification, the lower middle-income countries had a per capita income of $\$ 1,045-\$ 4,125$ at 2013 prices. The upper middle-income range was $\$ 4,126-\$ 12,745$, again at 2013 prices.
} 
Like India, Indonesia might well begin to constitute a democratic exception in an otherwise nondemocratic Southeast Asian region, where democratization should have been greater in Thailand and Malaysia, both upper middle-income countries, and, even more so, in Singapore, a high-income country whose per capita income now exceeds that of the United Kingdom, the former colonial master, France, and Germany respectively. ${ }^{5}$

\section{Why ResiLIENT?}

Statistically grounded theories tend to be probabilistic, not deterministic. They sketch the odds without suggesting that the outcome is tightly foreordained. After all, even for Przeworski et al. (2000), income, the best predictor of democracy, correctly predicted slightly over three-fourths of the democratic cases worldwide, leaving a little less than a fourth of the cases out. For decades now, India, still a lower middle-income country, has not belonged to the income-based democratic club, and Indonesia might also not. Factors other than income must be invoked to explain their democratic success-very substantial for India and, if the current trends continue, perhaps for Indonesia in the future, too. ${ }^{6}$

As I recently argued, a threefold explanation for India's democratic success can be given. ${ }^{7}$ The first has to do with the ethnic structure of the Indian polity and society; the second, more important one concentrates on how Indian nationalism was constructed during the long freedom movement; and the third addresses how democracy was anchored by the post-independence leadership, especially Jawaharlal Nehru, India's prime minister for seventeen years after independence, elected three times in free elections, and one of the biggest forces behind India's democratic constitution. I will discuss the first two factors here and turn later to Nehru and his normative orientation when I compare his arguments with those about Asian values.

If we go by the seminal conceptual distinction coined by Horowitz (1985), India has a dispersed, not centrally focused, ethnic system. Virtually all social identities in India are local or regional. Caste exists everywhere, but no single caste has a nationwide resonance. As a political category, caste gets mobilized only regionally. Language, too, is regionally based, and there are more than twenty official languages. Tribes are concentrated in central and northeastern India, but each tribe is different from the other. Only the Hindu-Muslim religious cleavage, when activated, threatens to acquire a near-national dimension, but its main force is felt in the north and west.

As a result, the various forms of ethnic conflict, when they do break out, get bottled up in one region or part of the country. They do not pose an existential threat to the

\footnotetext{
${ }^{5}$ Based on the World Bank data (data.worldbank.org), accessed on October 4, 2015.

${ }^{6}$ For other assessments of Indonesian democracy, see Kunkler and Stepan (2013), and Aspinall, this issue.

${ }^{7}$ See the arguments in Varshney (2013a, chap. 1). These arguments extend further the ideas first developed in Varshney (1998) and Varshney (2000). For some other recent arguments, see Chhibber (2014) and Tudor (2013). Earlier explanations include Kohli (2001), Lijphart (1996), Rudolph and Rudolph (1987), and Weiner (1989).
} 
country. India has not had to choose between democracy and nationhood. If India's nationhood had been more gravely threatened, it is possible that India's leaders would have brought to an end democracy altogether. Historically, whenever a battle between national existence and democracy has broken out, the latter has rarely, if ever, won.

Furthermore, India's identities are crosscutting, not cumulative. Even the HinduMuslim cleavage, the worst fault line of Indian politics, gets moderated by the fact that India's Muslims speak the language of the region in which they live. Language thus crosscuts religion. The same applies to India's tribes, castes, and linguistic groups. This kind of ethnocommunal configuration is very different from, let us say, Sri Lanka. On the whole, the Tamils in Sri Lanka are religiously, linguistically, and, by some accounts, racially distinct from the Sinhalese. ${ }^{8}$ In the absence of crosscutting pressures, the Sinhala-Tamil conflict turned into one of Asia's nastiest civil wars, battering the nation's democracy for three decades. India has witnessed insurgencies, but without significant geographical spread. At no point, since independence, have the insurgencies affected more than 3.5 percent of the population (see Varshney 2013b).

Led by Mahatma Gandhi and his colleagues, India's freedom movement also presented an inclusive view of the nation, a view that was enshrined in the postindependence constitution. Exclusive constructions of nationalism were quite possible. In particular, given that British India was over two-thirds Hindu in the first half of the twentieth century, some groups sought to promote a Hindu nationalist definition of the Indian nation. But Gandhi and Nehru built a very different kind of politics. Their conception of a free India, the one that mobilized millions, had two clear modes of inclusion: religion and language. "The Hindus, the Muslims, the Parsis and the Christians who have made India their country are fellow countrymen," wrote Gandhi as early as 1909 (Gandhi [1909] 1938, 46). "All of us, to whatever religion we may belong, are equally the children of India with equal rights, privileges and obligations," argued Nehru in a historic speech entitled "A Tryst With Destiny," presented to the Indian Constituent Assembly at midnight on August 14, 1947, celebrating the birth of India's independence.

Leaders of the freedom movement also conceptualized India as a multilinguistic nation. Indeed, India's federalism is primarily linguistic. Each major language has a state of its own, with constitutionally assigned powers (Varshney 2013b). To facilitate interstate communication, a three-language formula was developed. The lingua franca of the state would be the medium of instruction in schools; in addition, two other languagesHindi, spoken by roughly 40 percent of the country, and English-would be taught. Each linguistic group would thus feel secure about its power, but also have the ability to communicate in, and build links with, the larger nation.

According to John Stuart Mill, "free institutions are next to impossible in a country made up of different nationalities. Among a people without fellow feeling, especially if they read and speak different languages, the united public opinion, necessary to the working of representative government, cannot exist" (Mill [1861] 1990, 382; emphasis added). India has defied this prognosis, too, in addition to the income-based one. The leaders of the freedom movement were clear that Indians would have what we now

${ }^{8}$ In isolated parts of the country—for example, in Negombo-Christian Tamils and Christian Sinhalese can be found. An overwhelming proportion of each, however, is Hindu and Buddhist respectively. 
call hyphenated identities: Gujarati Indians, Bengali Indians, Tamil Indians, and so on. The nation was not to be conceptualized in a nineteenth-century European way. Instead of "one language, one nation," India went for what came to be termed "composite nationalism." Stepan, Linz, and Yadav (2011) have coined a new term for it: instead of a nation-state, India chose to be a "state-nation," institutionally safeguarding linguistic diversity instead of seeking its erasure. Most scholars and observers of Indian politics agree that if India had tried to impose a language (or religion) on the entire country, fratricidal violence would have undermined democracy. That is exactly why, when Hindu nationalists come to power in Delhi-they have done so three times, including currently-and a Hindu view of the nation emerges from the interstices of politics, intellectual and political concerns about the nation and democracy also come to the fore. Thus far, the constitutionally enshrined protection of diversities has constrained the Hindu nationalist project. ${ }^{9}$

\section{Asian Values}

In his discussion of Asian values, Thompson analyzes two different strands of thinking. First is the well-known definition, popularized by Lee Kuan Yew, which identifies social consensus, the priority of community over the individual, and the superiority of social and economic rights over political rights as core Asian values. In this reading, a Western-style adversarial democracy is an unsuitable form of polity for Asia. For the second strand, Thompson usefully turns to Kim Dae Jung, Aung San Suu Kyi, Abdurrahman Wahid, and Anwar Ibrahim, who use different cultural traditions in Asia to make the case that "popular participation" and "justness of opposition to despotic rule" also constitute core Asian values. If anything, these values support democracy in Asia. Perry adds that if mainland China's popular opinion uses cultural arguments to reject "electoral democracy," Taiwan and Hong Kong, both part of the larger Chinese tradition, have by now no such opposition in mind.

Did India’s leaders link democracy to Asian or Indian values? What was their rationale for why India should be a democracy? Nehru, of course, is central to answering these questions. While most of India's freedom fighters were committed to democracy, no one else argued more fervently, untiringly, and consistently.

Nehru's case for democracy in India was only secondarily cultural. He would, now and then, indeed say that freedom of thought and conscience was a hallmark of Indian culture and history (Nehru 1942, 129), and also noted that, according to the Arthashastra, "the king must bow to public opinion" (199). But he would also state that Hindu religious books did not contain "an inventory of rights," only "lists of dharmas, functions and duties” (Nehru 1946, 253). The caste system, in particular, provoked his ire. "There can be no equality in status and opportunity in its framework, nor can there be political democracy, and much less, economic democracy" (532). In short, India's ancient cultural traditions were an ambivalent source of democratic aspiration. Some traditions supported democracy; others obstructed it.

Nehru's primary case for democracy took two forms. First, it was opposed to colonialism. After India's mass mobilization, the British rulers had already introduced limited

\footnotetext{
${ }^{9}$ For the implications of India's Constitution for Hindu nationalists, see Varshney (2014).
} 
franchise and elections during late colonialism, but most power rested with the British. Nehru equated a fuller democracy with anti-colonialism and self-rule (Smith 1958, 44).

But Nehru's arguments about democracy continued even after the British left. These more philosophical arguments, some already made during colonial times, are anchored in the belief that freedom is absolutely necessary for the development of individuals and society: "Civil liberty is not merely for us an airy doctrine or a pious wish, but something which we consider essential for the orderly development and progress of the nation" (Nehru 1948, 67). Elsewhere, he argued that enlargement of franchise, including everyone, poor and rich, educated and uneducated, was based on the great twentieth-century premise, wrongly dismissed earlier, that "each person should be treated as having equal political and social value” (Nehru 1942, 528). This was also the reason why, despite admiring the Soviet Union for its massive economic achievements in the 1930s and 1940 s, he would claim that "communism, for all its triumphs in many fields, crushes the free spirit of man" (cited in Smith 1958, 46). Nehru often said that he came from a humanist liberal tradition. That is the tradition on which he finally rested the case for democracy, not on the cultural values of India or Asia.

A brief reference to Perry's arguments may also be in order here. Perry suggests that the Chinese conception of democracy has more to do with Rousseau than Schumpeter, with populism rather than elections. Rousseau, she says, is closer to the Chinese concept of "minzhu," which translates as "the sovereignty of the people." Nehru's biographers note that he had read Rousseau. But for him, there was no question of interpreting popular sovereignty without elected representatives. "Elections were an essential and inseparable part of the democratic process and there was no ... doing away with them" (Nehru 1946, 53). Election campaigns sometimes disappointed him, for they built frenzy and were noisy instead of favoring rational arguments, but democracy without elections was incomprehensible.

\section{LiBERALISM AND DEMOCRACY}

We have now sampled the arguments Nehru used to anchor the early years of Indian democracy. A violent partition, wars with Pakistan and China, and integration of semisovereign princely states - there were over 600 of them at the end of British rulemade those years very difficult for the polity. Nehru's leadership clearly was central to the development of democracy. The first elections-in 1952 - took six months to complete, and were described as a leap of faith (see Guha 2007, 137-59). Two more elections before his death, freely contested, institutionalized the electoral process in India.

Yet it is worth asking how deeply shared Nehru's ideas were among the masses, or by the politicians. That democracy is the only way to come to power is now the institutionalized common sense of Indian politics and politicians. After Indira Gandhi's emergency rule, which lasted eighteen months in 1975-77, no serious politician has proposed overturning the constitution. The military remains firmly in the barracks.

But India's continuing electoral vibrancy coexists with some democratic inadequacies, especially between elections. These democratic insufficiencies can be conceptualized as liberal deficits. The two most important deficits are the commitment to freedom of expression and the belief in the equality of citizens. 
India is at its freest at the time of elections. Short of inciting violence, virtually any argument can be made in election campaigns. But once an elected government takes over, it often seeks to place restrictions on liberty. Intellectuals, writers, artists, and nongovernmental organizations can face harassment on grounds that they hurt the sentiments of certain groups or undermine national interest. In a multireligious society, which has, in addition, had a deeply hierarchical caste system for centuries, some group or the other can always claim to be hurt.

Thus, Salman Rushdie could not participate in a literary festival because the Muslim right, citing previous injury to religious sentiments, threatened disorder. M. F. Husain, India's leading painter of his generation, had to leave the country because the Hindu right found his paintings religiously objectionable. Writers have been physically attacked, their books burned or banned; nonconforming intellectuals have been threatened; social media has been periodically censored; and NGOs have sometimes been taken to court for doing their job of working for the subaltern, and their financing, if foreign, cut off.

While these problems are common to all kinds of governments, they become especially serious when Hindu nationalists come to power. Minorities then get added to the list of targets. A mob led by Hindu nationalists lynched a Muslim man recently because they suspected that he ate beef, which, according to Hindu nationalists, amounts to an attack on Hindu beliefs and hurts Hindu feelings. Churches can be vandalized because Christians converted Hindus in the past, mosques because Islam preaches proselytization and converted Hindus, too.

While in all cases the courts remain available to the aggrieved individuals or families, the judicial process can take an inordinately long time, trapping individuals in webs of harassment and grave financial distress. Courts do constrain arbitrary conduct of governments, but governments know that in the short run power is on their side and the courts would normally take long to subdue the executive or bureaucracy. The pressure mounted by opposition parties works best. But when the latter are weak, India's commitment to liberalism suffers. In effect, India's democracy is more liberal when opposition parties are strong, meaning they have done well at the elections, though not won power.

India is also at its most equal at the time of elections. The state machinery can be unkind, even ruthless, towards the poor between elections, but all political parties systematically court the poor during election campaigns. The poor, the lower castes, and the rural citizens now vote in very large numbers (Ahuja and Chhibber 2012; Banerjee 2014). Over the last two and a half decades, India's democracy has gone through a plebian revolution (Jaffrelot and Kumar 2009).

Caste inequalities have also gone down, more so in southern India than in northern India (Varshney 2012). Upper castes, if not financially well off, are willing to "marry down," especially if the lower castes are richer (Ahuja and Ostermann 2015). But the idea that fellow citizens are equal remains only partially anchored in mass consciousness. The notion that citizens have rights vis-à-vis the state has gone farther than the idea that fellow citizens are equal. What Weber called vertical citizenship (citizen rights vis-à-vis the state) is stronger than what Tocqueville called horizontal citizenship (citizen rights with respect to each other). ${ }^{10}$

\footnotetext{
${ }^{10}$ For evidence from a recent urban survey, see Bertorelli et al. (2014). For a more conceptual discussion, see Jayal (2013).
} 


\section{ConcLusion}

In the introductory essay for this symposium, Chirot has argued that only a deep commitment to individual freedom can anchor a democracy. India's democratic record shows the necessity to separate the electoral and liberal aspects of democracy. Electorally, India is on stronger ground than it is with regard to classic liberal freedoms. Moreover, while some of the most atrocious inequalities, especially those with respect to caste, have been reduced, the idea of equality continues to encounter difficulties.

Despite liberal gaps, democracy continues to function. The electoral process is now deeply institutionalized. Democratic theory calls India’s electoral record exceptional, but in another sense, India’s democratic battles are only half won.

\section{List of References}

Ahuja, Amit, and Pradeep Chhibber. 2012. "Why the Poor Vote in India: 'If I Don't Vote, I Am Dead to the State." Studies in Comparative International Development 47(4): 389-410.

Ahuja, Amit, and Susan L. Ostermann. 2015. "Crossing Caste Boundaries in the Modern Indian Marriage Market.” Studies in Comparative International Development, May 8. doi:10.1007/s12116-015-9178-2.

Banerjee, Mukulika. 2014. Why India Votes? New Delhi: Routledge.

Barr, Michael D. 2014. “Singapore's Lee Kuan Yew: Traveling Light, Traveling Fast.” In Makers of Modern Asia, ed. Ramachandra Guha, 244-66. Cambridge, Mass.: Belknap Press of Harvard University Press.

Bertorelli, Ebony, Patrick Heller, Siddharth Swaminathan, and Ashutosh Varshney. 2014. Citizenship in Urban India: Evidence from Bangalore. Janaagraha-Brown Citizenship Index Study. Bangalore: Janaagraha.

Boix, Carles, and Susan C. Stokes. 2003. "Endogenous Democratization.” World Politics 55(4):517-49.

Chhibber, Pradeer. 2014. Religious Practice and Democracy in India. New York: Cambridge University Press.

Dahl, Robert A. 1971. Polyarchy: Participation and Opposition. New Haven, Conn.: Yale University Press.

1989. Democracy and Its Critics. New Haven, Conn.: Yale University Press.

Gandhi, Mahatma. [1909] 1938. Hind Swaraj. Ahmedabad: Navjivan Press.

Guha, Ramachandra. 2007. India after Gandhi: The History of the World's Largest Democracy. New York: Harper Collins.

Honowitz, Donald. 1985. Ethnic Groups in Conflict. Berkeley: University of California Press.

Jaffrelot, Christophe, and Sanjay Kumar, eds. 2009. Rise of the Plebeians? The Changing Face of Indian Legislative Assemblies. New Delhi: Routledge.

Jayal, Niraja Gopal. 2013. Citizenship and Its Discontents: An Indian History. Cambridge, Mass.: Harvard University Press.

Kohli, Atul, ed. 2001. The Success of India's Democracy. Cambridge: Cambridge University Press. 
Kunkler, Mirjam, and Alfred Stepan. 2013. "Indonesian Democratization in Theoretical Perspective." In Democracy and Islam in Indonesia, 3-23. New York: Columbia University Press.

Lijphart, Arend. 1996. “The Puzzle of Indian Democracy: A Consociational Interpretation." American Political Science Review 90(2):258-68.

Menta, Uday Singh. 1999. Liberalism and Empire: A Study in Nineteenth-Century British Liberal Thought. Chicago: University of Chicago Press.

Mill, John Stuart. [1861] 1990. Three Essays. New York: Oxford University Press.

Nehru, Jawaharlal. 1942. Glimpses of World History. New York: John Day.

—. 1946. The Discovery of India. New York: John Day.

1948. The Unity of India. New York: John Day.

Przeworski, Adam, Michael Alvarez, Jose Antonio Cheibub, and Fernando Limongi. 2000. Democracy and Development: Political Institutions and Well-Being in the World, 1950-1990. New York: Cambridge University Press.

Rudolph, Lloyd I., and Susanne Hoeber Rudolph. 1987. In Pursuit of Lakshmi: The Political Economy of the Indian State. Chicago: University of Chicago Press.

Schumpeter, Joseph A. 1947. Capitalism, Socialism, and Democracy. 2nd ed. New York: Harper.

Smith, Donald Eugene. 1958. Nehru and Democracy: The Political Thought of an Asian Democrat. Bombay: Orient Longmans.

Sridharan, E. 2014. "Class Voting in 2014 Lok Sabha Elections: The Growing Size and Importance of the Middle Classes.” Economic and Political Weekly 49(39):72-76.

Stepan, Alfred, Juan Linz, and Yogendra Yadav. 2011. Crafting State-Nations: India and Other Multinational Democracies. Baltimore: Johns Hopkins University Press.

Tudor, Maya. 2013. The Promise of Power: The Origins of Democracy in India and Autocracy in Pakistan. Cambridge: Cambridge University Press.

Varshney, Ashutosh. 1998. "Why Democracy Survives." Journal of Democracy 9(3):36-50.

—. 2000. "Is India Becoming More Democratic?" Journal of Asian Studies 59(1):3-25.

- 2012. "Two Banks of the Same River? Social Order and Entrepreneurialism in India." In Anxieties of Democracy: Tocquevillean Reflections on India and the United States, eds. Partha Chatterjee and Ira Katznelson, 225-56. New Delhi: Oxford University Press.

—. 2013a. Battles Half Won: India’s Improbable Democracy. New Delhi: Penguin.

—. 2013b. "How Has Indian Federalism Done?” Studies in Indian Politics 1(1):43-63.

—. 2014. "Hindu Nationalism in Power?" Journal of Democracy 25(4):34-45.

Weiner, Myron. 1989. "Institution Building in India." In The Indian Paradox: Essays in Indian Politics. New Delhi: Sage.

Yadav, Yogendra. 2000. "Understanding the Second Democratic Upsurge." In Transforming India: Social and Political Dynamics of Democracy, eds. Francine Frankel, Zoya Hasan, Rajeev Bhargava, and Balveer Arora, 89-119. New Delhi: Oxford University Press. 